\title{
THE STRATEGIC PARTNERSHIPS AS AN INSTRUMENT OF THE EU'S ACCOMMODATION TO THE EMERGING MULTIPOLAR ORDER
}

\author{
Jovan Manasijevski, MA in Political Sciences, PhD candidate in European Integration, \\ Department of Sociology, Ss Cyril and Methodius University
}

\begin{abstract}
The paper analyzes the EU's strategic partnerships as an important instrument of the Union's accommodation to the changed international constellation. The emergence, development and institutionalization of the strategic partnerships are treated in the context of the emerging multipolar order and the increasing global interdependence. The key formal, substantive and functional parameters of the established EU's strategic partnerships are analyzed. At the same time the main advantages and disadvantages are detected, offering number of dilemmas for further discussions. The analyses shows that through the development and institutionalization of the strategic partnerships, the EU profiles itself as a desirable strategic partner on the map of the new multipolar order. Launching and development of the strategic partnerships represents an attempt of avoiding the danger, or, more precisely, timely facing the real threat of the EU's irrelevance as an international actor. The strategic partnerships should provide effective execution of the CFSP in a function of realization of the EU's objectives and protection of the Union's interests. In a polycentric world, with fragmented and diffuse distribution of power between different, already established, as well as new emerging actors, in terms of growing interdependence, the strategic partnerships should enable the Union a global visibility and recognition, an efficient frame for optimal realization of its economic interests and continual expansion and deepening the spheres of cooperation, creating real basis for a long-term sustainable system of international relations.
\end{abstract}

Key words: strategic partnerships, multipolar order, accommodation, Common foreign and security policy, European Union

The European Union has timely perceived and has begun to adapt to the changed international constellation - the emerging new multipolar order. Unipolar world, characteristic for post-bipolar period, transits into multipolar, although there is still strong 
asymmetry in the distribution of power between established and emerging global actors. The unipolar moment, as it was predicted, was just a hall of the new-coming order (Krauthammer, 1990). An order which is characterized by a decrease of the global domination of the US and gradual supplementation of vacuum by some already established, as well as new global actors. Processes of redistribution of power, primarily the economic one, are followed by the growth of capacities for mutual balancing of the power and needs for collective action as a result of coexistence of more actors with considerable power. First, a rapid transfer of power from West to East can be registered. This transformation is of economic and geopolitical nature and a number of key indicators speak about it. But, on the other hand, of great importance are two other strong and quick transfers of power aimed at displacing the real power of the state actors: from states to the sub-states entities and from states to the regional organizations. Both transfers are strongly connected with the phenomena of globalization and ask for appropriate responses in the required adjustment of the behavior and actions of the states which are still main actors in the international relations. All the above-mentioned transformations eventuate in simultaneous continuation of two large, complex, defining processes in the international relations - multipolarisation and multilateralization.

At the same time, it can be noted that a well set strategic objective of the EU for a multilateral order as a systemic solution for the most important global problems cannot frame the fast-transforming reality. The international system transits from multilateral arrangements to multipolar system, where a rising marginalization of multilateralism can be noted (Drent and Landman, 2012:2). And more specific, "an increasingly multipolar and fragmented international system, characterized by power shifts and fragile institutions, which in turn makes effective multilateralism a noble but at times unattainable goal" (Missiroli, 2013:4).

In this gap between the strategic objective of building a global order based on effective multilateralism and the emerging reality of establishing new multipolar order, strategic partnerships are created as a flexible instrument which should enable continuous realization of the key economic and political interests of the Union, while building a broader framework for long-term and sustainable cooperation which should result in a system of responsible global governance.

For correct and appropriate thematization of the strategic partnerships, along with the emerging multipolarity, the irreversible trend of interdependence is of great importance, i.e. the mutual dependence of entities is crucial, whether they are state or non- 
state actors, in the realization and protection of their interests. In its scope and depth the former, mainly trade interdependence, gets new complex dimensions and evolves into a comprehensive interdependence which concerns the essential security parameters of the countries.

\section{Basic parameters of the strategic partnerships as a new CFSP's instrument}

Throughout the whole period since the adoption of the European Security Strategy (ESS) in 2003, the European Union was strongly committed to the developing of the strategic partnerships with all centers of global influence. Over a period of ten years the EU has launched and developed ten strategic partnerships with third countries and five strategic partnerships with other regional organizations or groups of countries.

It is said in ESS that the EU should realize its objectives "both through multilateral cooperation in international organizations and through partnerships with key actors" (European Council, 2003:28). In this document, the transatlantic partnership is treated as the most important, which is qualified as irreplaceable, but, at the same time, it is noted that the objective should be "an effective and balanced partnership with the USA". In the ESS Russia is also explicitly treated, and it is said that the Union should continue developing closer relationships with Russia, which is "a major factor for security and prosperity of the Union". Also, the need of developing strategic partnerships with Japan, China, Canada and India is highlighted (European Council, 2003:28). Five years later, in the revised security strategy, i.e. in the "Report on the implementation of the ESS", in the chapter "Partnerships for effective multilateralism" special importance is given to the strategic partnerships with other international organizations, especially with the UN, NATO, OSCE and the African Union (European Council, 2008:11).

The legal basis of the strategic partnerships as a tool of the CFSP is given explicitly in the Articles 21 and 22 of the Treaty of Lisbon. The Article 21 states: "The Union shall seek to develop relations and build partnerships with third countries and international, regional or global organizations which share the principles of democracy, the rule of law, the universality and indivisibility of human rights and fundamental freedoms, respect for human dignity, the principles of equality and solidarity and respect for the principles of the UN Charter and international law" (European Union, 2010). The Article 22 gives the competence for implementing these provisions to the European Council, where it is said that "On the basis of the principles and objectives set out in Article 21, the European 
Council shall identify the strategic interests and objectives of the Union" (European Union, 2010).

The analysis of the strategic partnerships shows that they are quite divergent. A part of them, especially those with the longest tradition and greatest content fulfillment are procedurally speaking, actually informal. The strategic partnerships with the USA, Canada, Japan and Russia are of such character. Most of the strategic partnerships are formalized, but formalization took place via various procedural mechanisms, partly through the Summits, as in the case of China, India, Brazil and South Korea, partly with Joint Action Plan, as in the case of South Africa, or through the Conclusions of the European Council as in the example of Mexico. There are also significant differences in the degree of institutionalization among individual strategic partnerships, too.

Table 1: Strategic partnerships of the EU with state actors - basic parameters

\begin{tabular}{|l|c|c|c|c|c|}
\hline & Since & $\begin{array}{c}\text { Annual } \\
\text { Summit }\end{array}$ & $\begin{array}{c}\text { Ministerial } \\
\text { dialogues }\end{array}$ & $\begin{array}{c}\text { Sectoral } \\
\text { dialogues }\end{array}$ & $\begin{array}{c}\text { Other } \\
\text { platforms }\end{array}$ \\
\hline USA & 1995 & 1 & 7 & 56 & 3 \\
\hline Canada & 1996 & 1 & 1 & 38 & 2 \\
\hline Japan & 2001 & 1 & 1 & 34 & 3 \\
\hline China & 2003 & 1 & 8 & 51 & 3 \\
\hline Russia & 2003 & 1 & 2 & 35 & 2 \\
\hline India & 2004 & 1 & 1 & 27 & 3 \\
\hline Brasil & 2007 & 1 & 1 & 31 & 2 \\
\hline S. Africa & 2007 & 1 & 1 & 18 & 1 \\
\hline Mexico & 2010 & biennial & 1 & 9 & 2 \\
\hline S. Korea & 2010 & 1 & $/$ & $/$ & $/$ \\
\hline
\end{tabular}

Source: EEAS

Looking at the content, the economic, mainly trade and investment parameters are essential for the strategic partnerships with third countries. In the official conclusions of the European Council from September 2010 it was stated that the strategic partnerships with key actors are a useful tool for the realization of the European objectives and interests, with particular note to the "strengthening of the trade with strategic partners as a key objective" (European Council, 2010:I.,4.). 
However, in recent years the EU has expanded the strategic partnerships with emerging global actors with security and foreign policy content, too. Thus, starting from 2010 the EU has already had an institutionalized form - High-level dialogue on foreign and security issues with China, under the direct leadership of the EU High Representative for Foreign and Security Policy. With India similar institutionalized form is implemented regular consultations on issues in the domain of foreign policy, also under the guidance of the High Representative.

Security parameters the most widely understood, within the identified security threats in the revised ESS, are essential for strategic partnerships with other international organizations and groups of countries. This particularly refers to the cooperation with NATO in a wide range of security issues, with UN in the operations for peacekeeping and crisis management, with the African Union in its preparation for creating their own sustainable forces for crisis management on the African continent (European Council, 2008:11).

\section{The main functions of the strategic partnerships}

Based on the content analysis of the existing strategic partnerships and the experiences of their implementation, as well as the secondary literature produced so far that thematize them, we can conclude the following most important functions of strategic partnerships as a CFSP's instrument.

Pragmatic function. Strategic partnerships are basically designed to provide a framework for managing bilateral relations between the EU and third countries. They should facilitate the realization of economic interests, above all, trade and investment. It is evident from their own content. Although there are significant differences between strategic partnerships with individual countries, yet they all have one common denominator - in each of them trade relations and investment agreements have key position. It is quite understandable if you look at the parameters listed in the table: 
Seccurity

Table 2: Selected parameters for the EU and its strategic partners

\begin{tabular}{|l|c|c|c|c|c|}
\hline & $\begin{array}{c}\text { share of } \\
\text { total EU } \\
\text { exports \% } \\
(2014)\end{array}$ & $\begin{array}{c}\text { share of } \\
\text { total EU } \\
\text { imports \% } \\
(2014)\end{array}$ & $\begin{array}{c}\text { share of world } \\
\text { GDP \% (2012) }\end{array}$ & $\begin{array}{c}\text { average } \\
\text { annual } \\
\text { growth \% } \\
(2000-2013)\end{array}$ & $\begin{array}{c}\text { population } \\
\text { (in mil.) } \\
\text { (2013) }\end{array}$ \\
\hline EU & & $22,9 \%$ & $1,7 \%$ & 506 \\
\hline Brasil & $2,2 \%$ & $1,9 \%$ & $3,1 \%$ & $3,4 \%$ & 200 \\
\hline India & $2,1 \%$ & $2,2 \%$ & $2,7 \%$ & $7,3 \%$ & 1.252 \\
\hline Japan & $3,1 \%$ & $3,2 \%$ & $8,2 \%$ & $1,3 \%$ & 127 \\
\hline S. Africa & $1,4 \%$ & $1,1 \%$ & $1,0 \%$ & $3,4 \%$ & 53 \\
\hline S. Korea & $2,5 \%$ & $2,3 \%$ & $2,2 \%$ & $4,1 \%$ & 50 \\
\hline Canada & $1,9 \%$ & $1,6 \%$ & $2,1 \%$ & $2,2 \%$ & 35 \\
\hline China & $9,7 \%$ & $18,0 \%$ & $11,5 \%$ & $9,8 \%$ & 1.357 \\
\hline Mexico & $1,7 \%$ & $1,1 \%$ & $2,3 \%$ & $2,9 \%$ & 122 \\
\hline Russia & $6,1 \%$ & $10,8 \%$ & $2,8 \%$ & $4,8 \%$ & 143 \\
\hline USA & $18,3 \%$ & $12,2 \%$ & $22,3 \%$ & $2,1 \%$ & 316 \\
\hline
\end{tabular}

Sources: Eurostat, World Bank, European Comission

Positioning function. This is an extremely important, basically reflexive function of strategic partnerships. With their launching and continuous realization, the EU provides an important function of its positioning, directed towards profiling and building perception of itself as a global actor. Through the development and further institutionalization of strategic partnerships, the EU profiles itself as a desirable strategic partner, i.e. it becomes a subject on the map of the emerging new multipolar order.

Normative function. Although they are basically an instrument of the bilateral cooperation, in a context of the EU's normative discourse the strategic partnerships have a function of strengthening international cooperation directed towards building an order based on effective multilateralism and global governance. This means that the EU is capable to shape the international norms projecting global power by promoting its values and principles (Manners, 2002, 2006). "The most important factor shaping the international role of the EU is not what it does or what it says, but what it is" (Manners, 2002:252). The EU's normative power lies in its capability to shape new standards in the international policy, since the EU rests its operations with member-states and with the surrounding 
world based on universal norms and principles (Manners, 2002:239-241). Or, more explicitly "the ability to define what passes for 'normal' in world politics is, ultimately, the greatest power of all "(Manners, 2002:253).

Integrative function. This function derives from the needs and obligations that the strategic partnerships produce themselves for their successful realization. By setting itself as a subject in the strategic partnerships, the EU is required to tend towards achieving a higher level of coherence in the use of the various instruments available for the realization of its interests. Additionally, the operationalization of the CFSP through the instrument of strategic partnerships requires deepening the political cohesion of the Union and intensification of cooperation between member states in the domain of foreign policy, i.e. a higher level of harmonization of the national policies.

In the context of the integrative function, it can be noted that the strategic partnerships are a tool for gradual, careful transfer of the foreign policy interests of the member states from national to supranational and intergovernmental level, as can be seen by the fact that, viewed by the content, in the strategic partnerships, key national interests of the most powerful countries of the Union are clearly embedded and visible. Does it compromise strategic partnerships as a tool of the CFSP, leading to their instrumentalization in the function of the most powerful member states, or, on the contrary, it gives proper weight in the sense that the key distinctive national interests of the member states can be successfully embedded, integrated and implemented through the instruments of the CFSP?

\section{The strategic partnerships and other CFSP's instruments}

By the change of the international constellation, there is an occurrence of adaptation of the CFSP's instruments themselves, as well as their relative importance within the total available toolbox. With the emergence of a new multipolar order, the strategic partnerships gain higher priority. But their full effectiveness is only possible if they are well balanced with the other instruments, especially with the effective multilateralism, focused neighbourhood policy and the completion of the enlargement process.

The instrument of EU enlargement has proved indispensable for the EU aspirations to gain weight and power of a global actor. With the enlargement in the last decade, the EU has nearly doubled the number of its member states, as well as its total population and 
territory. The enlargement will continue until a territorial completion of a certain sustainable geopolitical space that should be highly integrated occurs.

The instrument of European neighbourhood policy is naturally attached to the enlargement, as an instrument of pacification, adaptation and directing the development in the areas outside of the EU's projected borders. European neighbourhood policy "can be understood in terms of an ongoing project of re-territorialisation that combines traditional geopolitical concerns and a 'politics of regional difference' with a post-national focus on mutual interdependence and partnership" (Scott, 2009:232).

Effective multilateralism is an essential concept of the distinctive European approach to the international relations. "In a world of global threats, global markets and global media, our security and prosperity increasingly depend on an effective multilateral system" (European Council, 2003:19). Therefore, special attention should be paid to the mutual relationship of the strategic partnerships and effective multilateralism. On one hand, there is the view of the strategic partnership as an instrument of effective multilateralism, i.e. the interpretation that although strategic partnerships are bilateral instrument, they should simultaneously connect and converge bilateral, minilateral and multilateral formats and thus to be functionalized in achieving the main objective - effective multilateral order (Grevi, 2010,2012; Gratius, 2011). On the other hand, the strategic partnerships and effective multilateralism can be seen as competitive tools in the arsenal of a pragmatically realpolitik oriented CFSP. At certain times or certain situations they can be compatible, but if the EU aspires to function in the format of a strong international actor, it shouldn't and mustn't be enslaved by its normative narration and to put its available instruments for the purpose of that narration at any cost, but rather pragmatically, from case to case, depending on its interests, to use the most appropriate instrument. Sometimes it is a strategic partnership, sometimes a multilateral arrangement.

However, if the new global order is being developed outside the framework of effective multilateralism, the EU's weight on the global stage will be relatively small, because it, as a Union, has no tradition of action in the framework of realpolitik (Renard, 2012:4). Therefore, to maintain its relevance in the international arena, the EU must actively strive towards shaping a multilateral order, where it because of its own constitutive experience is on a well known field. In this context it is worth to remind ourselves of the deeply rooted warnings of the neorealistic school of thinking that a multipolar order which is not 'balanced' or situated in multilateral frameworks is extremely dangerous and confrontational system of international relations (Waltz, 1979). 
An interesting and inspiring synthetic interpretation of these phenomena is the socalled interpolar order. Namely, the concept of interpolarity represents a synthesis of multipolarity and interdependence, where basically it has been argued that any established or emerging global power will be limited in its power by highly growing connectivity and interdependence in all key domains - economy, energy, security, environment. An "existential interdependence" has been diagnosed, that inevitably leads all global actors towards cooperation rather than towards conflicts (Grevi, 2009). Thus it comes to a model of multilateral multipolar order as an anticipated optimal outcome of current trends.

\section{The relevance of the strategic partnerships - observations and dilemmas}

Current as well as previous thematizations of the strategic partnerships have imposed some dilemmas, allowing space for critical understanding of their role and importance.

Above all, the dilemma for the EU status as a strategic partner - whether it has already been assigned, predefined, constitutive, i.e. it is naturally derived from the total capacities and features of the Union, or independently of them, it should be recognized by its partners and should keep on confirming? Grevi considers that the status of a strategic partner of the $\mathrm{EU}$ is not given, but it must be recognized by its partners. At the same time, the already established as well as emerging centers of power also face strong pressures to continuous adaptation to the changes brought by more profound global interdependence. To get an effective tool the Union should design the strategic partnerships in a way that it will provide a delicate balance between its interests and its values. At the same time, taking into account the great diversity of individual strategic partners of the EU, there cannot be a universal recipe for the design and implementation of the strategic partnerships (Grevi, 2010, 2012).

The next important dilemma is related to the question of whether strategic partnerships are truly strategic by its "nature" or, they are more "ad hoc" partnerships. According to Renard, they lack the necessary comprehensiveness, but they are mostly focused only on the trade and economic issues. He believes that the EU doesn't cooperate with its strategic partners regarding the vital issues that really have strategic character (Renard, 2011). Close to this is the question of the character of strategic partnerships whether their character is active or mostly reactive? Even the President of the European Council himself, at the opening of the debate on strategic partnerships in this body, 
lapidary notes"... there are strategic partnerships, now we need a strategy" (Van Rompuy, 2010).

And, of course, the most important dilemma, the influence of the strategic partnerships as an instrument of the CFSP - are they with or without structural and institutional influence on the mutual relations of the strategic partners? In the context of the normative discourse of the EU, its foreign policy is aimed at strengthening international cooperation directed towards building an order based on effective multilateralism and global governance. In this context, it refers to the so-called structural foreign policy of the Union, which is based on high coherence between the internal and external policies and tends towards realization of its interests on a long-term and sustainable way within a global system based on rules and cooperation (Keukeleire and MacNaughtan, 2008:25-28). The structural foreign policy has a particular influence on the economic and social structures of the partners (regardless if they are states, regions or international organizations), it is implemented by peaceful means, and it is not conjunctural, but medium and long-term oriented (Telo, 2001). Sautenet, through detailed analysis of the EU strategic partnership with China, argues that strategic partnerships as instruments of 'soft law', which are complementary to the legal bilateral framework that defines the EU's relations with its partners, are developing simultaneously in two directions: as a para-legal instrument that gives dynamics to the economic cooperation, helps to come to the conclusion of sectoral agreements and integrates the political dimension; and, as a pre-legal instrument that enables partners to lay out achieving some new legally binding framework agreements (Sautenet, 2008:13).

A special interest causes the relationship between strategic partnerships with state actors and strategic partnerships of the EU with other regional organizations, so-called EU inter-regional strategies. It can be noted that in the last period the EU prefers the strategic partnerships with the states, at the expense of the strategic partnerships with the regions and regional organizations where these states belong. It can be interpreted as an indicator of mitigation of the strong multilateral ambitions of the EU at the expense of adaptation to the imperatives of the realpolitik. But it raises the question whether the EU in this way, by forcing bilateral arrangements with particular regional power, discourages or has a negative influence on the regional integration under its own model. Does it also mean a weakening of the capacity for projection of its integration model in other parts of the world, i.e. weakening of the normative power of the EU? 


\section{Concluding remarks}

The strategic partnerships as an important instrument of the CFSP in its form and content are quite heterogeneous. In the context of the growing complexity of the system of international relations, especially in the light of the emerging multipolarity and accelerating interdependence, they are flexible and multifunctional part of the Union's toolbox and as such provide broad opportunities for constant adjustments for better extent of the priorities of the partners and for changes of their profile on the global stage.

The strategic partnerships as an instrument of the EU's CFSP have been established to enable the Union to operate globally in a changed international constellation. The main task of the strategic partnerships is to enable adjustment of the EU to the ongoing transformation towards a multipolar order. The creation of strategic partnerships is an attempt to avoid the danger, or, more precisely, timely confronting the threat of potential irrelevance of the Union as a global actor, if accommodation does not occur timely. Due to the rapid transformation of the international order, the design of strategic partnerships as an instrument of the required continuous accommodation is flexible. For critics of this instrument it is unfinished, very flexible, devoid of substantiality. But on the other hand, these identified "deficiencies" give it the necessary flexibility and openness to transformation in order to perform its functions effectively.

The strategic partnerships should ensure effective implementation of the CFSP in order to realize the objectives and protect the interests of the Union. In a polycentric world, with fragmented and diffuse distribution of the power between different, already established as well as new emerging actors, in terms of growing interdependence, the strategic partnerships should enable the Union a global visibility and recognition, an efficient frame for optimal realization of its economic interests and continual expansion and deepening the areas of cooperation, creating real basis for long-term sustainable system of international relations, a system which is capable to provide a responsible global governance, as the only possible response to the growing global issues and challenges.

\section{References}

1. Drent M. and Landman L. 2012. Why Europe needs a new European Security Strategy. Policy Brief. The Hague: The Clingendael Institute.

2. European Council. 2003. European Security Strategy: A Secure Europe in a Better World. Brussels. 
3. European Council. 2008. "Report on the Implementation of the European Security Strategy: Providing Security in a Changing World". In EU Security and Defence: Core documents 2008 vol.IX, edited by Gliere C. 2009. Chaillot Paper 117. Paris: EU ISS.

4. European Council. 2010. Conclusions. EUCO 21/1/10, Brussels, 12 October 2010.

5. European Council. 2010a. "Strategic partners Progress report", 16-17 December, www.europolitique.info/pdf/gratuit-fr/285183-fr.pdf

6. European Union. 2010. "Consolidated versions of the Treaty on the European Union and the Treaty on the Functioning of the European Union", Official Journal of the European Union, C 083, 30 March 2010.

7. Eurostat. 2014. The EU in the World: A Statistical Portrait. Luxembourg: European Union.

8. Георгиева Л. 2010. Европска безбедност. Скопје: УКИМ - Филозофски факултет.

9. Gratius S. 2011. Can EU Strategic Partnerships deepen multilateralism? Madrid: FRIDE.

10. Grevi G. 2009. The interpolar world: a new scenario. Paris: EU ISS.

11. Grevi G. 2010. Making EU strategic partnerships effective. Madrid: FRIDE.

12. Grevi G. 2012. Why EU strategic partnerships matter. Madrid: FRIDE.

13. Grevi G. and Vasconcelos A., eds. 2008. Partnerships for effective multilateralism: EU relations with Brazil, China, India and Russia. Paris: EU ISS.

14. Keukeleire S. and MacNaughtan J. 2008. The foreign policy of the European Union. London: Palgrave Macmillan.

15. Krauthammer C. 1990. "The Unipolar Moment". Foreign Affairs, vol.70, no.1, pp.2333.

16. Manners I. 2002. "Normative Power Europe: A Contradiction in terms?". Journal of Common Market Studies, Volume 40, Number 2, pp.235-258.

17. Manners I. 2006. "Normative Power Europe reconsidered: Beyond the Crossroads". Journal of European Public Policy, Volume 13, Number 2, pp.182-199.

18. Missiroli A. 2013. Strategic foresight - and the EU. Paris: EU ISS.

19. Renard T. 2011. The Treachery of Strategies: A call for true EU Strategic Partnerships. Egmont Paper 45. Gent: Academia Press.

20. Renard T. 2012. The EU Strategic Partnership Review: Ten Guiding Principles. Madrid: FRIDE. 


\section{Securilaty}

21. Sautenet A. 2008. Europe and China: Cooperation with Complex Legal Dimensions. Paris: Institut Francais des Relations Internationales.

22. Scott J.W. 2009. "Bordering and ordereing the European Neighbourhood: A critical perspective on EU Territoriality and Geopolitics". Trames, 13(63/58), 3, pp.232-247.

23. Shapiro J. and Witney N. 2009. Towards a Post-American Europe: a Power Audit of EU-US Relations. London: European Council on Foreign Relations.

24. Smith M. and Xie H. 2010. "The European Union and China: The Logics of 'Starategic Partnership'". Journal of Contemporary European Research, Volume 6, Issue 4, pp.432-448.

25. Telo M. 2001. "Reconsiderations: Three Scenarios". In European Union and New Regionalism: Regional Actors and Clobal Governance in a Post-hegemonic Era, edited by Telo M. Aldershot: Ashgate.

26. Ванковска Б. 2010. Институциите на ЕУ: до Лисабон и по него. Скопје: УКИМ Филозофски факултет.

27. Van Rompuy H. 2010. Message of President Van Rompuy, European Council, Sept. 2010.

28. Waltz K. 1979. Theory of International Politics. McGraw-Hill.

29. World Bank. 2015. World Development Indicators. Washington DC. 